\title{
'N UITSIG VANUIT DIE KOSMIESE WERK VAN DIE RÜAH OP DIE PNEUMATOLOGIE?
}

Die vraagstelling na die Pneumatologie vanuit die perspektief van die kosmiese werk van die rûah kan met 'n vraagteken, 'n ontkenning of 'n uitroepteken beantwoord word. '1 'n Teologies verantwoordbare keuse kan egter slegs in die lig van die betekenisspreiding en die woordhegting van die term rûah begrond word. Dit is die oogmerk van die onderhawige artikel om aan dié onderneming uitvoering te gee.

\section{Die rûaḥ en die skepping van die kosmos}

Daar kan instemming met Jonker betuig word as hy beweer: "Daar is niks in skepping, herskepping en voleinding wat nie deur die Gees gedoen word nie $^{\prime \prime}{ }^{2)}$ En tog verteenwoordig die verhouding Gees en skepping 'n probleemveld. ${ }^{31}$ Dit bring mee dat die aard van die verhouding nagevors moet word. Die opdrag om die verband tussen die rûah en die skepping te ondersoek, is onontwykbaar. Des te meer omdat die werk van die Gees in die Nuwe Testament as her-skepping bely word. ") Westermann reken: "Man kann nicht verstehen was im NT pneuma heisst, wenn man nicht die Geschichte des Wortes ruah im AT kennt. ${ }^{\prime 5)}$ Rûah en pneuma kan egter nie probleemloos as sinonieme gebruik word nie. Daarom is Blaser se voorstelling té simplisties as hy beweer: "eine Überprüfung der Bedeutung und Auffassungen von 'ruah' und 'pneuma' im AT und im NT ergibt, dass der Heilige Geist als 'Gott in Aktion' erscheint." ${ }^{\text {"6) }}$ Rûah ontvang sy betekenis in die Ou-Testamentiese teks en binne die konteks waar dit voorkom. ") Die werkwoorde wat met rûah verbind is, kan byna uitsluitlik in twee groepe verdeel word: 1. werkwoorde van beweging en 2 . werkwoorde van in-beweging-bring. Die klem val nie op die aard van die beweging nie, maar op die feit van die beweging as sodanig. ${ }^{8}$

Die eerste teksgedeelte wat in aanmerking kom om die band tussen die rûah en die skepping van die kosmos te verduidelik, is Gn 1:2: "Die aarde was heeltemal onbewoonbaar, dit was donker op die diep waters". Dan volg die omstrede sleutelsin: "... maar die rûạ "æohîm het oor die waters gesweef".

'n Oorsig oor die verklaringspogings om die sin van die rûah-sin op te klaar, bied die volgende moontlikhede:

1. Dit kan as die locus classicus beskou word om die skeppende aktiwiteit van die Heilige Gees te bewys. "In die lig van latere gegewens, veral in die Nuwe Testament (maar blykbaar tog nie slegs in die Nuwe Testament nie C.J.A.V.I, sal by 'n vertaling soos 'die gees (of die adem) van God' onwillekeurig aan die Heilige Gees gedink word." '9) Latere gegewens, veral in die

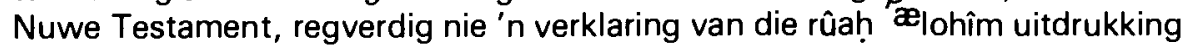


vanuit die Nuwe Testament nie. Die grondvraag is wat die outeur met die segging bedoel het. Hy het beslis nie die Heilige Gees in Nuwe Testamentiese sin in sy blikveld gehad nie. Daarvoor is die Ou Testament te eksklusief monoteïsties (Dt 6:4). Die poging van Van Zyl om vanuit die Ou Testament die uitdrukking rûah Jhwh ('ælohîm) aan die Heilige Gees gelyk te stel, word ook deur genoemde beswaar in die ongelyk gestel. ${ }^{10}$

2. Van Selms stel die volgende vertaling voor: "Maar Gods wind zweefde over de wateren en God zeide ..." ${ }^{\prime 1}$ ) Hy bied die volgende motivering: op verskillende plekke in die Ou Testament gaan 'n wind die teofanie-handeling vooraf (vgl. Gn 3:8, II Sm 5:24, I Kon 19:12, Job 4:15, Ps 104:4). Dit beteken dat die wind ' $n$ voorbode van die Goddelike woord is (Gn 1:3). Van Selms is nie heeltemal eenling in sy opvatting nie. Scheepers is van oordeel dat die werkwoordsvorm wat die handeling van die rûạ 'ælohîm beskryf, met die beweging van 'n voël wat bo sy nes sweef, verband hou.12) Wanneer die swewende voël sy vlerke fladder, word daar' $n$ beweging van lug vrygestel. In die lig hiervan gee Scheepers voorkeur aan die vertaling "wind". Waar die windbeweging by Van Selms ' $n$ voorbode van die teofanie-handeling is, is dit by Scheepers ' $n$ voorbode van die windstryd teen die water as chaosmag. Die wind is daarop uit om die chaoswaters weg te blaas. Scheepers wys in dié samehang op talle plekke waar die roering van die water deur God voorkom (vgl. Job 26:8-14, Ps 18:16, Ps 107:25). Die gedagte van die beheersing van die water deur God by die Rooi See, kom binne God se heilshandelinge na vore (Eks 14:21-22). ${ }^{13}$ ) Scheepers se verklaring kan egter maklik daartoe aanleiding gee dat daar duistere magte in die chaoswater woel - en dit nog vóór die raaiselagtige sondeval (Gn 3 ). Van Selms se verklaring dat die wind van God ' $n$ voorloper van sy verskyning is, dra daarom meer gewig.

3. König maak beswaar teen Van Selms se vertalingskeuse op grond van sintaktiese redes. Hy is van oordeel dat die eerste en tweede sinsegmente van vers 2 wat bymekaar hoort, nie van die derde segment geskei kan word nie. ${ }^{14}$, Volgens Kónig is die tweede en derde sinsnedes "waarskynlik" parallelle uitsprake en hoort die derde frase ook nog by die chaostekening. ${ }^{15}$ ) Op grond van die sintaktiese inbedding van die sinsegmente van vers 2 , kies hy self ietwat huiwerig ten gunste van die NEB-vertaling: "mighty wind". De Fraine het dié vertaling reeds vroeër voorgestaan. ${ }^{16)}$ Westermann wys daarop dat die uit-

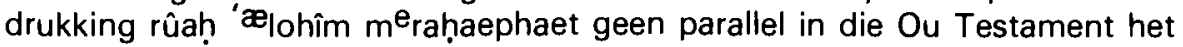
nie. In die lig van die feit dat die werkwoord op "die zitternde oder vibrierende Bewegung" konsentreer, kan rûah in dié verbinding wel wind beteken. ${ }^{17}$ ) 'Aelohîm kan ook adjektiwies in die sin van 'n superlatief as magtige, "furchtbarer Wind" verklaar word. ${ }^{18)}$

4. Hoenderdaal is van mening dat die water in Gn 1 méér is as 'n blote natuurverskynsel. Die chaoswater is ook die plek waar die bose woon (Rahab, Leviatan, vgl. Jes 51:9, Ps 46). God heers egter ook oor die chaosmagte. ${ }^{19}$ 
Hoenderdaal gee deur dié weergawe aan die bose 'n broeiplek wat dit hoegenaamd nie verdien nie. Hy kom tot die volgende slotsom: "De verbinding van Geest met de kracht van de wind laat ons zien hoe ook in Genesis het de kracht van God is, die als wind boven de duisternis van de watervloed zweeft en de wereld schiep." "20) Die swakheid van Hoenderdaal se standpunt is egter dat hy tegelykertyd twee betekenisse soos twee vlerke aan een woord wil heg. Daarom verklaar hy: "Hoezeer de betekenis 'wind' zich in Genesis 1 opdringt, toch blijft de notie 'Geest' ermede verbonden."21)

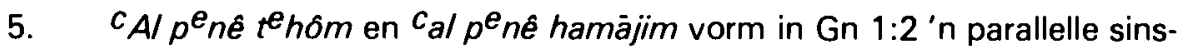
konstruksie. Die parallelle uitdrukking versterk in samehang met die onbewoonbaarheid en die donkerte, die skildering van die chaostoestand voordat God orde-nend en ook skeppend handel. Die pi. vorm van die werkwoord rhph beskryf in dié toestand die beweging van die rûah 'ælohîm. ${ }^{22)}$ Dit gaan in die beweging van die rûah om méér as net 'n beskrywing van ' $n$ "Gottessturm" (Von Rad, Westermann, Zimmerli) of 'n "magtige wind" (De Fraine, Westermann, Von Rad, König). Die omskrywing "wind van God" (Van Selms, Scheepers, Berkhof) waai ook nie genoeg helderheid nie.

Gn 1:2" ("maar die rûah 'ælohîm het oor die waters gesweef") vorm 'n antitetiese parallel met $\mathrm{Gn} 1: 2^{b}$ ("en dit was donker op die diep waters").

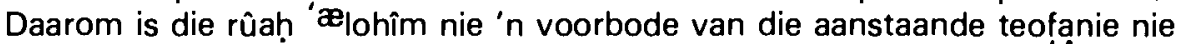
(Van Seims), en ö́ók nie deel van die chaosskildering nie (König). 'Aelohîm word in die eerste skeppingsvertelling ( $\mathrm{Gn} 1: 1-2: 4^{a}$ ) deurgaans as ' $n$ Naam vir God gebruik. Daarom pleit die teksverband teen die opvatting om ' $\mathfrak{T}_{\text {lohîm in }}$ verbinding met rûah adjektiwies in die sin van 'n superlatief as 'n "magtige wind" te vertaal (König, Westermann). Uit die sintaktiese waarneming dat Gn

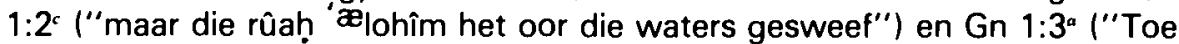
het God gesê ...") ietwat losser geheg is, kan ook nie afgelei word dat Gn 1:2 geen uitsig op Gn 1:3 bied nie (König).

Die rûah verklaar dat God vir die skepping v(V)ader staan en daarom op 'n bepaalde wyse by sy onbewoonbare skepping teenwoordig is. Rûah is ' $n$ besonder geskikte woord om God se skeppende teenwoordigheid te verduidelik. Dié woord wys daarop dat God in beheer van die situasie is. Daarom is rûah 'n manifestasie van God se skeppende mag. ${ }^{23)}$ God se skeppende mag beweeg oor die chaos om in die donker lig te laat skitter. Dit is juis sý skeppende mag (Gn 1:2) wat uitsig op sy skeppende woord bied (Gn 1:3). ${ }^{24}$ )

Om saam te vat: die ruah "ælohim is God se skeppende mag in beweging.

Aangesien die rûah in Ps 33:6 in verband met die skepping van die kosmos gebruik word, kom die gedeelte ook in aanmerking vir nadere oorskouing. Theron maak op voetspoor van Berkhof die volgende opmerking: "Skeppingswoord en Skeppingsgees is onlosmaaklik verbonde". ${ }^{25}$ ) Ps 33:6 dien as 'n bewysgrond vir sy stelling. Theron verstaan in die konteks van sy beredenering waarskynlik onder "Skeppingsgees" die Heilige Gees. Hierteenoor moet opgemerk word dat die woord van Jhwh en die rûạ van sy 
mond (33:6) 'n parallelismus membrorum vorm. ${ }^{26)}$ Däbär en rûah is in die konteks komplementêre begrippe. As God sy woord spreek, gaan die asem uit sy mond. ${ }^{27}$ Asem verteenwoordig lewe en daarom kan die rûah in die teksgedeelte God se skeppende mag in sy skeppingshandelinge aandui.

Die betekenisveld "asem" het reeds implisiet in die voorafgaande gedeelte voorgekom. Dié betekenisveld speel ook in op die verstaan van die volgende gedeeltes. Asem is nie net beleef as iets wat blywend teenwoordig is nie, maar as ' $\mathrm{k}$ krag wat in die asemritme sigbaar word. ${ }^{28)}$ Dit is teen dié agtergrond dat die betekenislading van rûah in die skeppingskontekste nagegaan moet word. Die twee voor-eksiliese tekste wat hiervoor in aanmerking kom, is Gn 6:3 en Gn 7:22. ${ }^{29}$ ) Gn 6:3 lewer probleme op wat betref sy teksvorm en konteks. Dié teks is nie ingeweef in die patroon van $\mathrm{Gn} 6: 1-4$ nie. ${ }^{30)}$ Hieruit maak Albertz en Westermann die gevolgtrekking dat die teks in sy huidige vorm, 'n verwerking is. ${ }^{31)}$ Rûahi kan in dié teks as lewensbeginsel verstaan word. ${ }^{32}$ ) Die lewensasem (as beginsel van die lewe) beteken eenvoudig "die Lebendigkeit, das Einhauchen des Lebensatems die Belebung des Menschen, nichts weiter". 33) In Gn 7:22 kom rûah ook in die betekenis "lewensasem" voor ${ }^{34)}$ Ons tref rûah verder in Jes 57:16 in die sin van lewensasem aan (vgl. Job 27:3). ${ }^{35)}$ Die asem wat God gee, wek die mens immers op tot lewe.

Ps 104:30 kan ook binne die voorafgaande raam geplaas word. Maar voordat dié plasing gedoen word, moet daar stip na die teks gekyk word. Die voorkoms van rûah in Ps 104:30 in verband met die skepping, het daartoe gelei dat dié teks oorspan is in 'n poging om rûah met "Gees" te vertaal. As Theron beweer "alles wat bestaan, bestaan kragtens die 'Mitsein Gottes' (Schumann) in die Heilige Gees" en Ps 104:30 as bewysplaas aanhaal, dan gaan die opmerking mank aan 'n eksegeties-teologiese peiling van die begrip rûah in die Ou Testament. ${ }^{36)}$ Pannenberg ken aan die Gees nie slegs ' $n$ soteriologiese funksie toe nie, maar ook 'n kosmiese werking. Hiermee is saaklik nie fout te vind nie. Maar wanneer hy sy stelling egter op Ps 104 grond, verloor sy bewering oortuigingsgrond. ${ }^{37)}$ Moltmann beweer met stelligheid: "Blickt der christliche Glaube auf die 'Schöpfung im Anfang' zurück, dann wird er schon in ihr die Präsenz des heiligen Geistes als Schöpfergeist entdecken. Er kann keine geist-lose Auffassung der Schopfung entwickeln. Die Schöpfung existiert nur in der Kraft des Geistes Gottes der in sei eingegangen ist. Sie würde vergehen, nähme Gott seinen Geist von ihr". Hy steun ook op Ps 104:29-30 vir sy standpuntinname. ${ }^{38}$ ) Berkhof beweeg op dieselfde baan as hy sê: "Gods Geest schept het leven van de natuur en houdt het in stand", en Ps 104:30 as bewysplek aanhaal. ${ }^{39}$ )

Ps 104:30 het nie die een-malige skeppingshandeling van God in die oog nie. ${ }^{40)}$ Maar kragtens God se skeppende mag (rûaḥ) leef mense en onderhou Hy sy skepping. "1) Die skeppende mag van God word deur die rûah verteenwoordig. Daarom is dit in die konteks meer verantwoord om onder rûah die "lewensasem" wat God gee, te verstaan. ${ }^{42}$ '

Rûaḥ kry 'n ietwat ander aksent in Jes 42:5, hoewel die verskil tussen 
"lewensasem" en "lewe" eintlik meer 'n asemtoggie is! Albertz en Westermann is van mening dat rûah eers in die tyd van die ballingskap in samehang met die skepping van die mens voorkom. ${ }^{43}$ ) Nešāmā en rûah kom in Jes 42:5 as parallelle begrippe voor. ${ }^{44}$ ' Die moontlikheid dat die teksgedeelte 'n toespeling op Gn 2:7 bevat, kan nie uitgesluit word nie. ${ }^{45}$ ) Van der Meer wys daarop dat God in Jes 42:5 as die Skepper van die hemel en die aarde bely word en óók as Gewer van die lewe (rûaḥ) aan die mensheid. ${ }^{46)}$ Dié belydenis beoog om God se uniekheid en onvergelyklikheid te verkondig en om die oë óbk oop te maak vir die lewensmoontlikhede wat Hy gaan skep. ${ }^{47}$ )

'n Oorskouing van Ps 139 toon dat daar slegs op 'n indirekte wyse oor die rûah en die skepping gepraat word. 'n Himniese grondmotief omsoom dié Psalm. ${ }^{48}$ ) God word geprys omdat $\mathrm{Hy}$ die digter op 'n gedugte wyse geskep het (Ps 139:14). Aangesien die digter uit God se hand kom, is hy ook vir altyd in sy hand. Dit is in dié verband dat daar van die rûah sprake is (Ps 139:7). Rûah is hier ' $n$ parallelle begrip vir pānîm. ${ }^{49}$ ' Daarom wys rûah in Ps 139 op God se persoonlike teenwoordigheid. Hy oorsien alles en almal en voorsien in die behoeftes van sy vertrouelinge.

Op hierdie stadium kan enkele grondpatrone ten opsigte van die rûạ̣ en die skepping gekomponeer word:

1. Die komposisie geskied nie op literêre of historiese gronde nie, maar op grond van tematiese oorwegings.

2. Wanneer die term "Gees" in die Ou Testament gebruik word, mag dit nie die weg baan tot 'n self-standige belydenis aangaande die rûah in skeppingskontekste nie. Die monoteïstiese toonaard van die Ou Testament staar so 'n interpretasie eens en vir altyd in die weg. Daar is net één God (Dt 6:4). Wanneer rûah in verband met God gebruik word, bly dié begrip aan God verbonde en wel op so 'n manier dat dit God Self is wat skeppend en onderhoudend optree.

3. Die rûah is in Gn 1:2 God se skeppende mag in beweging. In Ps 33:6 word God se skeppende mag in sy skeppende handelinge bekendgestel.

4. Rûah kom ook in die betekenis van lewensbeginsel (Gn 6:3) en lewensasem (Gn 7:22, Jes 57:16, Ps 104:30) voor.

5. Die term kan ook lewe én lewensmoontlikhede beskryf (Jes 42:5).

6. Ps 139 het slegs implisiet betrekking op die rûah en die skepping. Rûah is hier God se persoonlike teenwoordigheid wat himnies besing word.

\section{Die rûah en die messias/ ${ }^{c}$ aebaed}

In hierdie paragraaf gaan dit om die boeiende verhouding tussen die rûah en 
die messias/ $/$ abaed. Dié verhouding dra soveel gewig omdat van hieruit belangwekkende grondpatrone onderskei kan word waarop daar in die Nuwe Testament voortborduur word. ${ }^{50)}$

Wildberger vermoed dat Jes $11: 1-9$ in dieselfde tydsraam as Jes $10: 27^{b}-34$ staan. ${ }^{51}$ ) Jesaja $10: 27^{b}$ voorspel dat ' $n$ vernietigende katastrofe op Jerusalem wag. Die vraag wat vanselfsprekend op die volk se lippe bewe, is of daar nog van 'n toekoms vir die Dawidshuis en Israel sprake is. ${ }^{52)}$

Die verrassende antwoord is dat die profetiese heilswoorde, ${ }^{53}$ ) ' $n$ nuwe heilsdaad vir die toekoms voorsien. ${ }^{54)}$ Dié koning op wie die profetiese oë gerig is, is die messias-koning. ${ }^{55)}$ Dit is opmerklik dat die messias-koning tog menslik voorgestel word. Hy sal ' $n$ af-stam-me-ling van Isaï wees (Jes 11:1) en daar sal by hom ontsag vir die heilige God wees. ${ }^{56)}$

Met die oog op die uitvoering van sy taak, sal die rûah Jhwh op die messias rus (Jes 11:2). Dit gaan om 'n blywende verhouding tussen die rûah Jhwh en die messias. ${ }^{57}$ ' Die verwysing na die rûah Jhwh in die taaktoerusting van die messias is belangrik omdat die rûah ' $n$ aansienlike rol in die ampstoerusting in die Ou Testament vertolk. Die kragwerking van die rûaḥ het die ampspersoon tot magtige heilsgerigte dade in staat gestel. ${ }^{58)}$ Met reg merk Wildberger op: "Es sind nicht ausschlieslich, aber doch vornehmlich königliche Charismata" waarmee die koningsgestalte van die messias geteken word. ${ }^{59)}$ Daarom is dit ook nie vreemd dat die dinamiese werking van die rûah Jhwh hier funksioneer nie. ${ }^{60)}$ Die rûah Jhwh sal aan die messias vaardighede verleen vir sy "ganz und gar unpolitische Regierung: Weisheit, Einsicht, Rat, Stärke, Erkenntnis und Jahwefurcht" ${ }^{61}{ }^{61}$ Die gawes waarmee die rûạ̣ hom sal toerus, is heilsgerig. Wysheid en insig is koningstermini (I Kon 3:11-12, 28, I Kron 22:12, Jes 10:13). Die rûah sal aan hom heerserswysheid gee om die alledaagse probleme te behartig. ${ }^{6 \dot{2}}$ ) Die messias sal ook deur die rûah Jhwh in staat gestel word om in ' $n$ bepaalde omstandigheid die regte besluite te neem. ${ }^{63)}$ Die rûah sal voorts aan hom raad in raadop-situasies gee sodat hy met sy regering sy beoogde doel kan bereik. ${ }^{64)}$ Hy sal ook die geestelike en fisiese krag ontvang om sy regering suksesvol te bestuur (vgl Jes 11:4). ${ }^{65}$ ) Die rûah Jhwh sal die messias verder in staat stel om in ' $n$ intiem persoonlike verhouding tot Jhwh te staan ${ }^{66)}$ en om Godsvrug te dra. ${ }^{67}$ )

Die feit dat die rûah Jhwh op die messias sal rus en hom met ampsgawes vir sy koningskap sal toerus, sal daartoe lei dat die messiaanse regering een van reg en betroubaarheid sal wees (Jes $11: 3-5){ }^{68)}$ Sy vredesryk sal die skepsel en die skepping omvat. ${ }^{69}$ ) Die rûah Jhwh sal hom in staat stel om God by die mense te verteenwoordig. ${ }^{70}$ ) Met reg maak Scheepers die afleiding "dat Jahwe self deur sy gees met die Messias sal wees". ${ }^{11}$

Wanneer Westermann in die lig van die gawes van die rûah beweer: "es ändert sich an dieser Aufzählung nichts, wenn man das Wort 'Geist' überhaupt weglässt," en verklaar dat die begrip 'n abstrakte betekenis verkry het wat niks spesifieks sê nie, ${ }^{72}$ laat hy nie reg aan die gerigtheid van die woord geskied nie. Die keuse van die term hang spesifiek saam met die verlening van ampscharismata aan die messias-kỏning. Dit is juis die rûạ̣ Jhwh 
wat die blywende werking daarvan verseker en sodoende die vestiging van die vredesryk borg. Skerper gestel: dit is Jhwh Self wat deur die rûah die vestiging van en die suksesvolle regering in die messias-ryk sal bewerk.

'n Volgende teksgedeelte wat ons noulettende aandag eis, is Jes 42 . In dié gedeelte word die verhouding tussen die rûạ en die 'aebaed Jhwh grondig toegelig. Die verhouding wat in Jes 42 aan die lig kom, funksioneer binne ' $n$ weldeurdagte komposisie van Jesaja $40-55 .{ }^{73)}$ Met reg voer Westermann 'n pleidooi dat die vier 'aebaedliedere allereens binne die samehang van Deutero-Jesaja se verkondiging verstaan moet word. ${ }^{74}$ ) Dit beteken dus dat die voorstelling en die optrede van die dienaar in die konteks en verkondiging van Deutero-Jesaja tot sy reg kom.

Die eerste 'aebaedlied begin met 'n oratio recta van Jhwh wat met die interjeksie hên die aandag op die dienaar fokus. ${ }^{75}$ ) Jes $42: 1$ is 'n "Präsentionswort" waardeur God die dienaar vir 'n opdrag aanwys. ${ }^{761}$

Teen die agtergrond van die gode se onvermoë om hulle godheid te bewys, roep Jhwh sy "getuie" na die voorgrond - sy dienaar. Hy is God se getuie deur wie Hy sy Godheid in woord en daad gaan bewys. ${ }^{77 \prime}$ Dié getuienis sal die dienaar aan die volke en óók voor God se volk aflê. Maar ten einde sy dienaar hiertoe in staat te stel, moet hy toegerus word. ${ }^{78}$ )

God stel sy dienaar in staat om sy roeping te vervul deurdat Hy sy rûah op hom laat kom (Jes 42:1). Deutero-Jesaja staan binne die tradisie waar die rûah ' $n$ mens tot diens bekwaam. Hiervan is die rigters, die ekstatiese profete, die 'Skrifprofete, die konings en die messias sprekende voorbeelde. ${ }^{79}$ ) Indien aangeneem kan word dat die dienaar óók oor koninklike kenmerke beskik, word daar veral uit die Dawidstradisie geput waar die rûah die koning vir sy amp toerus (I Sm 16:13, $2 \mathrm{Sm}$ 23:1 e.v., vgl. Jes 11:2).$^{80}$ ) Die verbale vorm wat die rûah-gawe beskryf, dui op 'n blywende kragwerking van God. Dit is juis die rûah as gawe wat die dienaar tot die uitvoer van sy taak inspireer en in staat stel.

Dit is van pas om samevattend op enkele gesigspunte wat uit die paragraaf rondom die tema rûah-messias/aebaed gekristaliseer het, te fokus.

1. Ten einde die messias in staat te stel om sy messias-regering te vestig, rus Jhwh hom toe met sy rûah. Die rûah verteenwoordig in die verband Jhwh se blywende teenwoordigheid.

2. Jhwh verleen deur die rûah aan die messias ampsgawes sodat hy as koning regverdig kan heers en as profeet kan leer en dien.

3. In die Ou Testament is die gesig van die dienaar (Jes 42) bedek. In die Nuwe Testament word die dienaar as die Messias, die Christus, ontdek. Hy lê oop en bloot in 'n noodwiegie. Die Messias lê en wag as't ware vir die doopdag. Dié dag waarop die 'aebaedlied ón Hom gesing sou word. Op dié dag sou die Gees op Hom kom rus om Hom vir sy taak toe te rus (Mk 1:10, 12). Die taak wat op Hom gewag het, was om God se 
wêreldomvattende koningsheerskappy te proklameer. Maar om dit te realiseer, moes $\mathrm{Hy}$ die heil versoenend bewerk sodat die Heilige Gees dit kosmies kon effektueer.

\section{Die rûah en die herskepping van God se volk}

Die ${ }^{c}$ aebaed se taak is op Israel én die volke gerig. Hiertoe het die rûah hom bekwaam. Daarom is dit 'n bekwame plek om nou op die verhouding tussen die rûah en die volk te let.

in die eksiliese en na-eksiliese tydvak is die opvallende dat die rûa in byna alle gevalle met die suffiks van die eerste persoon enkelvoud gebruik word ${ }^{81 '}$ Hieruit kan die afleiding gemaak word dat die rûah-voorstelling binne die Jhwh-rede plaasvind, veral binne die raam van die profetiese heilsaankondiginge en -skilderinge ${ }^{82}$ ) Hierdie heilsvoorspellings en -voorstellings open verrassende perspektiewe met betrekking tot die aktiwiteite van die rûah. Langs hierdie weg is daar op ' $n$ ongekende nuwe verhouding tussen God, mens en wêreld aangespeel.

Die omvattendheid van die rûah se werksaamheid ten opsigte van die ganse volk kan as herskeppende handelinge omskryf word. Die herskeppende werksaamheid funksioneer by Esegiël binne die raamwerk van Israel as God se ontroue bondgenoot. ${ }^{83)}$ Esegiël vertolk die heilsgeskiedenis as Jhwh se reeks onsuksesvolle handelinge met sy volk en Israel se konstante mislukking om die Goddelike wil na te kom. ${ }^{\text {84) }}$ Die ekskursie wat Esegiël van die geskiedenis onderneem, beoog nie om Israel se afsonderlike oortredinge aan die man te bring of om die mislukking voor een geslag se deur te lê nie, maar om die diep gewortelde onwilligheid om God heelhartig te gehoorsaam, aan die kaak te stel. ${ }^{85}$ ) Die groot raaisel is dat Israel nie in staat is om God te gehoorsaam (ken) nie. En dit ondanks God se trou. Dié onverklaarbare verhardheid kan slegs aan Israel se "kliphart" (Esg 36:26) toegeskryf word. Dit gaan nie slegs om "de hardnekkige, weerspannige gezindheid"86) nie, maar om 'n totale verdorwenheid wat op sondige gesindhede én dade uitloop. Die ongehoorsaamheid aan God konkretiseer in die ontheiliging van sy Naam onder die nasies (Esg 36:22-23) ${ }^{87}$ ) en die aanhang van die gode van die nasies (Esg 36:25). ${ }^{88}$

Die eer van Jhwh is op die spel, daarom handel Hy. ${ }^{89}$; Sy handelinge het die heiliging van sy Naam voor die nasies ten doel (Esg 36:23). Hy wil sy heiligheid - sy mag - voor die oë van die nasies deur sy heilsdade vestig..$^{90}$ ) God se herskeppende handelinge begin met reiniging (Esg 36:25). Op die reiniging van sonde (Esg 36:16 -38), volg die herstel van God se volk. Die reiniging word verbeeld in ' $n$ waterbesprinkeling wat ' $n$ kultiese reinheid voorstel. ${ }^{911}$

Aangesien Esegiël Israel se bestaan voor God met 'n priesterlike bewoëndheid beskryf, ${ }^{92}$ ) is dit ook nie vreemd dat hy die heil in kultiese terme doop nie.

Die rituele reiniging van die liggaam is egter net maar die begin. Op dié 
reiniging volg die vernuwing van die innerlike (vgl. Esg 11:19). Daar moet 'n radikale hartsverandering plaasvind. Die term leb is ' $n$ omvattende begrip. Dit is nie slegs die setel van die ganse ervaringslewe nie, maar ook van die verstand en wil. ${ }^{\text {93) }}$ Die hart kan in een woord beskou word as ' $n$ aanduiding van die wils- en aksiesentrum van die mens. ${ }^{94}$ ) Ten einde die wils- en aksiesentrum van die mens/volk te verander, is ' $n$ "nuwe hart en 'n nuwe gees" nodig (Esg $36: 26)$. Leb en rûah word as parallelle begrippe gebruik om die verandering wat Jhwh van binne uit bewerk, aan te dui. ${ }^{95}$ ) Dit gaan nie net om "een nieuwe gezindheid" nie, ${ }^{96)}$ maar om 'n hart-grondige lewensherskepping. Jhwh bewerk die herskepping deur sy rûah (Esg 36:27). Die rûah is 'n manifestasie van Jhwh se herskeppende krag. ${ }^{97}$ ) Jhwh skep deur sy rûah ruimte sodat die volk sy wil kan gehoorsaam (vgl. Esg 11:20). Die Godgegewe en gevraagde gehoorsaamheid bring 'n nuwe Gods-diens mee.

Die herskeppende handelinge van Jhwh deur sy rûah is nie "a pie in the sky when you die" nie. Jhwh se herskeppende handelinge gryp in die eksistensie van sy volk in. Daarom word daar in Esg 37 (ná Esg 36) na die implikasies van die herskepping vir die volk se (aardse) bestaan gekyk.

Israel vergaan van wanhoop in die ballingskapsnoute. Hulle rouklag lui soos 'n doodsklok. "Ons bene is uitgedroog, ons het geen hoop meer nie, dit is klaar met ons" (Esg 37:11b) ${ }^{98}$ ) In hierdie wanhoopsklag lê die verlies van alle vitale lewenskrag ingeklem. ${ }^{99}$,

Dit is in hierdie nulpuntsituasie dat Esegiël ' $n$ visioen sien: 'n gesig van wat Jhwh, die Herskepper gaan (kan) doen. Hy gaan naamlik nuut begin met 'n volk wat skynbaar (werklik!) aan sy einde gekom het. In die profetiese visioen staan die menslike onmag teenoor die Goddelike volmag (Esg 37:3) ${ }^{100}$ ) God gaan die verdorde bene (mense) laat herleef. Esegiël maak van die term rûah gebruik om die radikale herlewing te beskryf. Jhwh gaan lewe in die dooie bene blaas (Esg 37:5, 6, 9, 10, 14). ${ }^{101}$ ) In die lig daarvan dat Esegiël met skeppingsterminologieë werk om die herskeppingsgebeure te verduidelik, is dit nie vreemd dat die skepping van die mens in Gn 2:7' $n$ analoë gebeure is nie. ${ }^{102)}$ Die wonder van Jhwh se herskeppende daad blyk daaruit dat $\mathrm{Hy}$ die bleek bene uit die grafte haal (Esg 37:12). Die graf is immers die plek waar die dooie buite bereik van die lewende is. ${ }^{103}$ ) Esegiël maak van eksodusterminologie gebruik om Jhwh se herskeppingsdaad aan te dui: die uitkom uit die graf en die terugbring na Israel toe (Esg 37:12). ${ }^{104}$ ) Die uittog uit die land van die dood lei na ' $n$ intog in die land van die lewe. Die intog word aan die herskeppende werk van Jhwh se rûah verbind (Esg 37:14). Die rûah sal die tot die dood toe vertwyfelde volk weer tot lewe wek. ${ }^{105}$ ) Jhwh se rûah verteenwoordig hier sy herskeppende krag. Die wonder van die nuwe lewe vir die volk is die groot Godsbewys teenoor die wêreld - Jhwh skep die geskiedenis en Hy hou woord. ${ }^{106)}$

Jesaja 44:1-5 funksioneer ook binne die ballingskapsituasie. In dié gedeelte kom aan die lig dat Jhwh deur sy rûah sy volk met oorvloed seën. Die herskeppende werk van Jhwh se rûah word vergelyk met die uitgiet van water op droë grond (Jes 44:3). Soos water in die woestyn skielik 'n wonderbare 
lewe wek (Jes 41:19), só sal die rûah van Jhwh die skynbaar gestorwe volk tot nuwe lewe en groei opwek. ${ }^{107)}$ Dit is opmerklik dat die rûah en be räkã in Jes 44:3 as parallelle begrippe gebruik word. $\left.{ }^{108}\right)$ Hiermee word die oorvloed van die Goddelike seënwerking aangedui. ${ }^{109}$ ' Dit is die Goddelike seënwerking van die rûah Jhwh wat vir die hede (die volk) 'n toekoms (nakomelinge) skep. ${ }^{110}$ ) 'n Toekoms waarin die nakomelinge soos gras sal uitspruit - lewend en kragtig (Jes 44:4). 'n Toekoms waarin die volk van God óók deur proseliete verryk sal word. ${ }^{111)}$ En dit alles as gevolg van Jhwh se seënwerking!

Joël 2:28-32 is van groot be-teken-is om die werking van die rûah Jhwh onder die volk en sy uitwerking op die volk te teken. Op grond van God se heilsdade sal die belydenis ontstaan dat $\mathrm{Hy}$ i) in die midde van sy volk is en ii) dat Hý die enigste God is (Joël 2:26-27). ${ }^{12}$ ) Dit is dié belydenisformule wat ruimte skep vir ' $n$ heilstoesegging in die toekoms. Die toekoms word van hieruit in sy kosmiese wydte met nuwe lewenskrag deur die uitstorting van Jhwh se rûah gevul. Dit bly egter 'n oop toekoms. Daarom is die volk met gespanne haas en verwagting na die toekoms oppad. Die teksgedeelte is veral ook in Nuwe Testamentiese perspektief van belang. Want dié teksgedeelte (Joël 2:28-32) word in vervullingskategorieë met betrekking tot die heilsfeit van Pinkster hanteer (Hd 2:17-21).

Die onmiddellike aanleiding tot Joël se profesie is die sprinkaanplaag en die droogte wat daarmee saamgaan. ${ }^{113}$ ) Die sprinkaanplaag word in Joël 2:1-11 op 'n dramaties hiperboliese wyse beskryf waarin dit duidelik blyk dat dit om méér as net 'n sprinkaanplaag gaan. ${ }^{114)}$ Die sprinkaanplaag is ' $n$ teken van die onheil wat die verskriklike en skrikwekkende dag van die Here sal bring (vgl. Joël 1:15). In die lig van die dreigende gerig roep die profeet die priesters op (Joël 1:13) om die volk in die dag van boetedoening voor te gaan (Joël $1: 14)$. Die dag van onheil het ook 'n kosmiese gerigtheid (Joël 1:17-20). In Joël 2:18-4:17 vind 'n heilswending plaas - die onthulling volg dat die donker gerigsdag onheil vir die volkere in die "dal van Josafat" sal inhou, maar heil vir God se volk. ${ }^{115}$ )

Dit is binne die raam van die heilswending dat daar sprake is van die rûah Jhwh. Die voorspelling van die heilsbelofte bring mee dat Joël 2:28-32 vaniveë eskatologiese spanning tril. Want die toekoms sal 'n uitkoms bring op grond van die koms van die rûạ Jhwh. Die toekomstige koms van die rûah Jhwh word in ' $n$ kosmiese samehang gerangskik. Die kosmiese herlewing (Joël 2:21 -26) is ' $n$ voor-teken van die herskepping wat met die koms van die rûah Jhwh ' $n$ aanvang sal neem. ${ }^{116}$ ) Dit is opvallend dat die kombinasie $2: 28 b-29$ ' $n$ afgerondheid of inclusio vertoon deurdat dit sowel ingelei as afgegrens word met " $E k$ (sal) $m_{y}$ Gees laat kom". Hierdie perikoopseksie word dus omraam deur die uitspraak van Jhwh dat Hy sy rûah sal uitstort. ${ }^{117}$ Hierdeur word Jhwh se handeling sterk beklemtoon. Die uitstorting van sy rûah sal die gebeure in 2:28b-29 veroorsaak. ${ }^{118}$ ) Soos Jhwh deur die "uitgieting" van die reën nuwe lewe aan die kosmos gegee het (vgl. 2:24), so sal Hy vir sy volk nuwe lewenskrag deur die uitstorting van sy rûah gee. ${ }^{119}$ ) Die koms en werking van die rûah sal die hele /srae/ aangryp. ${ }^{120)}$ Die profeet ver- 
duidelik die uitdrukking "al die mense" volledig: Jhwh sal sy rûạ̣ aan die ganse volk gee sonder inagneming van leeftyd, geslag en sosiale status. ${ }^{121}$, Almal sal ingewydes van en toegewydes aan Jhwh wees. ${ }^{122}$ 'Die profeet sluit by die geykte tradisie van die ekstatiese profesie aan wat "profeteer", "drome droom", en "gesigte sien", maar dit verkry 'n heilsverbreding en verdieping. ${ }^{123}$ ) Die "charismata" is nie toegewys aan 'n uitverkorene soos die profeet of die koning nie, maar die hele volk is gevolmagtigde openbaringsmiddelaars. ${ }^{124)}$ Die versugting van $\mathrm{Nm}$ 11:29 ("Ek sou wou wens dat die hele volk van die Here profete was, en dat Hy sy Gees op almal mag lê") word in die heilsvoorsegging 'n uitsig. Die verhouding met God sal deur die herskeppingswerk van die rûah Jhwh nuut wees. ${ }^{125}$ ) Die belydenis dat die Here alleen God is, sal 'n belewenis word.

Daar sal ook kosmiese voor-tekens wees om die koms van die rûah Jhwh aan te wys. Daarom kan daar selfs van 'n kosmiese eskatologie gepraat word. Die tekens (Joël 2:30) word beskryf met geykte terminologie wat gewoonlik met Jhwh se toorn en oordeel verband hou. ${ }^{126)}$ Die tekens het die verskriklike en skrikwekkende gebeure wat met die plae oor Egipte gekom het, geteken ${ }^{127}$ ) (Eks 7:3, Dt 6:22, Neh 9:10, I Kron 16:12, Jr 32:20). Daarom kan die nuwe heilsera as 'n nuwe eksodus verwag word. ${ }^{128}$ ) Daar sou selfs van die eksodus van die rûah gepraat kon word. Die hiperboliese beskrywing van die voortekens wat die ganse skepping in beroering bring, onderstreep die radikaliteit van die nuwe heilstyd en Jhwh se handeling, ${ }^{129}$ ) maar óók onheil vir die nasies.

Waar die werking van die rûah Jhwh vroeër sporadies tot enkele uitverkore enkelinge soos die rigters, konings, profete, beperk was, ${ }^{130}$ ) kry dit nou onder die hele volk 'n blywende gerigtheid. Die lig van die herskeppende werking van die rûah Jhwh skitter egter nie slegs op God se volk nie, maar ook op sy skepping.

Die werk van die rûah met betrekking tot die skepping kom nou vanselfsprekend aan die bot.

\section{Die rûah en die herskepping van die skepping}

In die politieke en godsdienstige krisis wat die ballingskap veroorsaak het, het God se heilswoord tot teen die kosmiese wande geslaan. Marduk is in Babilonië as die skeppergod geroem. ${ }^{131}$ ' Wie is teen hom opgewasse? Israel se Skepper- en Verlossergod! Hý het die heelal gemaak voordat die sonde dit gekraak het. Die profeet (Jes 40:12-14), die priester (Gn 1:2) en die digter (Ps 33:6 - 7) getuig dat Jhwh deur sy skeppende mag (rûaḥ) alles (goed) gemaak het. ${ }^{1321}$

Die rûah verteenwoordig Jhwh se leweskeppende krag, maar ook sy herskeppende krag. Dié waarhede word in Jes 32:15-20 en Jes 11:6-9 bevestig. Die paragraaf in Jes 32:15-20 volg op die voorsegging van onheil. ${ }^{1331}$ Die oordeel sal alles in puin lê "totdat" die rûạ̣ kom. ${ }^{134}$ ' Die rûah sal van Bo af uitgestort word (Jes 32:15). Die plek vanwaar die rûah sal kom, is God se woonplek. Die 
rûah sal dus van God af kom, om kragtig en lewewekkend in die skepping te werk. ${ }^{1351}$ As Scheepers reken dat die kosmiese veranderinge dien om die nuwe lewe slegs te verbeeld, dan hou hy nie voldoende met die konteks rekening nie. ${ }^{136 l}$ Die koms van die rûah sal juis werklike skeppingsveranderinge bewerk. Die herskeppende werk van die rûah kan nie net in die menslike bestaan geprivatiseer word nie, maar die skepping sal óok tot by die eindes van die aarde grondig herskep word. Die mens het die ganse skepping immers in sy sondeval meegesleep (Gn 3:17-19).

Die herskepping van die mens in die heilstyd, sal ook 'n volledige kosmiese herskepping meebring. Die natuur sal deur die rûah herskep word. ${ }^{137)}$ Die woestyn as onbewoonbare plek vol bedreiging en doodsgevare $(\mathrm{Jr} 2: 6)^{138}$ ) sal ' $n$ vrugteboord word en die vrugteboord sal in ' $n$ welige bos omskep word (Jes 32:15). Só ryklik en vrugbaar sal die natuur herskep word. Die skepping sal 'n ruimte word waar die geregtigheid as etiese dimensie ${ }^{139}$, onder mense sal woon (Jes 32:16). Die woestyn sal nie meer 'n plek wees waar mense oor weiplek en bronne stryd voer nie en die kultuurland sal nie meer 'n plek wees waar mededinging en die verdediging van huis en haard tot ' $n$ regstryd sal lei nie. ${ }^{140}$ ' Aangesien daar reg geleef sal word, sal daar vrede wees (Jes 32:17). Die wêreld sal vol vrede wees! Die verband tussen geregtigheid en vrede is geyk. ${ }^{141}$ In die Ou Testament kom die verbinding veral in die eskatologies-gerigte profesieë voor (vgl. Jes 54:13-14, 60:17).142) Die nuwe waarby alles ingevoeg is (vrede!), bring mee dat daar geen bedreiging vir die skepsel én die skepping sal wees nie. Gelukkig is die boer wat in 'n paradys leef! Sonder die oog op die wolke kan hy lustig saai en die kudde kan sonder vrees vir roofdiere aanteel (Jes 32:20). As die sterre liggies reën, kan alles op die akker en die weiland gedy -- danksy die herskeppende werk van Jhwh se rûah!

In Jes 11:6-9 word dieselfde tema as in Jes 32:15-20 aangesny. Daar kom egter ander perspektiewe by. In die heilstyd sal die spruit van Dawid met die rûah toegerus wees vir sy heilsregering (Jes $11: 1-2$ ). ${ }^{143}$ ) Volgens Fohrer beteken die messiaanse tyd die terugkeer van die paradystyd ${ }^{144}$ en sien hy die tema van dié gedeelte as: die eindtyd bring die terugkeer van die oertyd mee. ${ }^{145)}$ Daar kan eerder van skeppingstyd in plaas van oertyd gepraat word. Die messiaanse tyd is óók méér as slegs ' $n$ terugkeer na die skeppingstyd. Die messiaanse tyd is nie net 'n natros (of natroos!) nie, maar herskepping. Daarom moet die kontinuiteit sowel as die diskontinuiteit van die messiaanse tyd ten opsigte van die skeppingstyd onverkort gehandhaaf word. Teen dié agtergrond is dit ook nie vreemd dat Jes $11: 6-9$ by die paradyssituasie aansluit om die messiaanse tydvak in kosmiese beelde te teken nie. ${ }^{146)}$ Daar sal vrede onder die diere heers - in so 'n mate dat roofdiere weidiere sal word (Jes 11:6). Die wolf en die skaap, die luiperd en die bokkie, die kalwers, leeus en voerbeeste sal een vredesgemeenskap onder die vredeshand van klein seuntjies wees (Jes 11:6). Daar sal ook vrede tussen mens en dier heers. Die vyandskap tussen mens en slang sal opgehef wees (Jes. 11:8, vgl. Gn 3:15). ${ }^{147)}$ Die vrede wat alle verstand te bowe gaan, sal tussen God en mens 
heers (Jes 11:9). Die aarde sal vol wees van die Godsgemeenskap soos die water die seebodem bedek. Die heil sal die hele wêreld oorspoel. Vrede sal kosmies rimpel. Dit sal alles plaasvind onder die heerskappy van die messias onder aandrang van die herskeppende werk van die rûah van Jhwh.

'n Slotwoord: Enkele gekonsentreerde perspektiewe kan ten opsigte van die voorafgaande twee paragrawe ( 3 en 4) aangetoon word:

1. Die twee paragrawe oor die rûah en die volk én die rûah en die skepping word as ' $n$ eenheid behandel aangesien die kosmos sowel die skepsel as die skepping omva'

2. Die rûah se handelinge ten opsigte van die volk is herskeppende handelinge. Die herskeppende handelinge staan binne die kader van die volk se raaiselagtige ontrou aan Jhwh. Dit bring mee dat die rûạ 'n hartgrondige lewensherskepping vir die volk bewerk.

3. Die herskeppende werk van die rûah is egter ook aards gerig. Dit is eksistensieel van aard. Die leweskeppende krag van die rûạ gee hoop aan ' $n$ hooplose volk in die nulpuntsituasie van die ballingskap. Dit is daarom die herskeppende krag van Jhwh se rûah wat die intog in die beloofde land sal realiseer.

4. Die heilstoekoms waarin die rûah van Jhwh uitgestort sal word, word as 'n oop toekoms voorsien. Die toekoms het 'n kosmiese wydte. Daarom is die herlewing van die skepping ' $n$ voor-teken van die herskeppingsgebeure waardeur die rûah nuwe lewenskrag aan die volk sal gee. Die herskeppingsdaad waarop die geloofsoog gevestig is, het die hele Israel in die oog. Alle onderskeid verval. Almal sal in die heilstoekoms ingewydes van en toegewydes aan Jhwh wees. Dié Gods-diens sal gemanifesteer word deurdat almal sonder aansiens van persoon, charismata sal beoefen. Die kosmiese voor-tekens wat die heilsdag voorafteken, be-teken die nuwe heilsera as Jhwh se genadige handelinge.

5. Waar die werking van die rûah in die ou tradisies rondom die ampte (rigters, sommige profete, konings, enkele enkelinge) insidenteel was, sal dit in die heilstoekoms blywend wees. Die rûah sal dan Jhwh se blywende inwoning bevestig.

6. Die herskeppende werk van die rûah Jhwh het veral ook 'n kosmiese reikwydte. Dit kan ook nie anders nie. Die rûah as Jhwh se skeppende mag het die kosmos geskep en sal daarom ook leweskeppend werk. Die skepping sal God se heil vier. Daarom sal die woestyn 'n ruimte word waar mense in reg en vrede sal leef. Deur die herskeppende krag van die rûah sal die heil van God die skepsel en die skepping omvat. Die paradys sal uiteindelik 'n nuwe hemel en 'n nuwe aarde word (vgl. Jes 66:221. 
Die betekenisspreiding en woordhegting van die term rûạ̣ bied in die raam van die voorafgaande uiteensetting, die volgende uitsigte ten opsigte van die probleemstelling in hoeverre en in watter mate daar van 'n uitsig op die Pneumatologie vanuit die Ou Testament sprake is:

Die eerste konklusie wat gemaak kan word, is dat die rûah nie naas of sonder Jhwh 'ælohîm optree nie. Hierdie conclusio word bevestig deur die onpersoonlike werkwoorde waarmee die koms en werking van die rûah beskryf word. ${ }^{148}$ ) Die vraag is egter of die gebruik van onpersoonlike werkwoorde om die koms en werk van die rûah aan te dui, voldoende steun bied om die afleiding te maak dat die rûah nie 'n persoon naas of sonder Jhwh is nie. Want daar is in die Ou Testament ander gedeeltes wat sterk persoonlike eienskappe van die rûah voorstaan. ${ }^{149}$ ) Daar word gesê dat die rûah praat $(2$ Sm 23:2), onderrig (Neh 9:20), lei (Ps 143:10) en bedroef kan word (Jes 63:10). 150) En tog kan daar nie op grond van die persoonlike handelinge van die rûah tot die gevolgtrekking geraak word dat dit om 'n persoon naas of sonder Jhwh gaan nie. In die hele Ou Testament geld die één belydenis: Jhwh alleen is God (Dt 6:4, Jes 43:10-12, 44:6). ${ }^{151}$ )

'n Volgende saak wat gewig dra is dat die rûah in die verbinding rûah

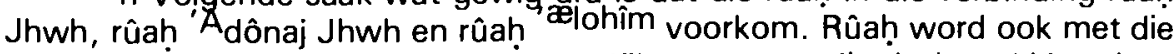
eerste, tweede en derde persoon suffiks wat op Jhwh betrekking het, aangetref. ${ }^{152)}$ Die rûah handel dus nie los van of sonder Jhwh nie. Hieruit kan daar afgelei word dat die rûah Jhwh-in-aksie is. Daar kan daarom met reg van die rûah as die manifestasie van Jhwh se teenwoordigheid gepraat word. ${ }^{153)}$ Wanneer die rûah soms in die Ou Testament as 'n persoon voorgestel word, kan daar aan die stylfiguur van personifikasie gedink word. ${ }^{154)}$ Die bewering word bevestig deurdat die rûah in die latere tyd 'n algemene term geword het. ${ }^{155)}$ Die rûah beskryf nou nie meer 'n besondere daad van God nie, maar God as sodanig. Die "Gees van God" word nou byna gelykbetekenend met "God" sodat dit in talle tekste nie meer saak maak of die "Gees van God" of "God" die Subjek is nie. ${ }^{156)}$ Só sou "sy Gees" in Jes 34:16 en "die Gees van die Here" in Jes 63:14 net sowel met "die Here" vervang kon word. In Ps 139:7 word "u Gees" en "u teenwoordigheid" parallel gebruik. Dit wys daarop dat die Here Self bedoel word. ${ }^{157}$ ) In Jes 63:10,11, 14, is die Gees 'n sinoniem vir die "Ek" van God. 158) In Jes 30:1 dui die rûah van die Here op sy innerlike (vgl. Jes 40:13 en 63:10).159) Dit is opmerklik dat die uitdrukking "rûah qodschô" slegs in Jes 63:10 en 11 voorkom, terwyl "rûah qodschekă" net in Ps 51:13 gebruik word. Westermann wys daarop dat die woord rûạ in dié verband ' $n$ algemene Goddelike predikaat geword het wat die wese van God omskryf. ${ }^{160}$ )

Die voorafgaande getuienis bevestig die bewering dat die rûạ̣ God-inaksie of God Self aandui. Scheepers, ${ }^{161)}$ Jonker ${ }^{162)}$ en Vosloo ${ }^{163)}$ kan daarom nie nagevolg word as hulle die rûah as ' $n$ hipostase van Gơd beskọu nie. Die vraag is natuurlik wat onder hipostase verstaan word. ${ }^{164)}$ Scheepers beskryf 
hipostase aan die hand van die beroemdgeworde definisie van $\mathrm{H}$. Ringgren. "Es bezeichnet eine oft nur halb selbständige göttliche Wesenheit, die eine mehr oder weniger durchgeführte Personifizierung einer Eigenschaft, einer Wirksamkeit oder irgendeines Attributes einer höheren Gottheit darstellt." Vosloo omskryf hipostase as "die verpersoonliking van God se werksaamhede en attribute op so 'n wyse dat dit die voorkoms van 'n half-persoonlike goddelike Wese kry." ${ }^{166}$ ) Vir dié definisie beroep Vosloo hom op Scheepers en Eichrodt. ${ }^{167)}$ Eichrodt maak op sy beurt weer van Ringgren se omskrywing gebruik. ${ }^{168)}$ Dit blyk dus kristalhelder dat Ringgren se definisie die oorspronklike omskrywing is waarop die woord hipostase gebou is. Dié term kan egter om teologiese redes nie op die rûah-begrip toegepas word nie. Want die rûah van God is ten enemale nie 'n half-selfstandige Goddelike wese nie. Daar is nie in die Ou Testament plek vir halwe gode nie. Dáár is net één God!

Die vraag is egter of Jonker nie tog reg het as hy beweer dat dit verkeerd is "om in die Pneumatologie van die Ou Testament uit te gaan of om die Ou-Testamentiese uitsprake oor die Gees deurslaggéwend te maak vir die leer aangaande die Gees ..." nie. ${ }^{169)}$ As daar nie van die Gees as Persoon in die Ou Testament sprake is nie, is dit dan nie ' $n$ teenspraak om in die Pneumatologie van die Ou Testament uit te gaan nie? Tog kan die standpunt gehandhaaf bly dat daar wel vanuit die Ou Testament oor die Pneumatologie gedink moet word. Die Ou-Testamentiese spreke oor die rûah bied 'n uitsig op die Nuwe Testament omdat die Nuwe Testamentiese insig die rûah-uitsprake binne vervullings- (vgl. Jl 2:28-32 en $\mathrm{Hd} \mathrm{2:17-21)} \mathrm{en} \mathrm{verwysingskategorieë}$ hanteer (vgl. Hd 2 en Jh 3). In die Nuwe Testament word onthul dat die Persoon en die werk van die Heilige Gees nie sonder die agtergrond van die Ou Testament verstaan kan word nie. In die Ou Testament word aan die belydenis van die eenheid van God vasgeklem. Dié belydenis word nie in die Nuwe Testament geloën nie, maar daar kom 'n spreiding in die openbaring oor God. In die Nuwe Testament vind die openbaring van die Meervoud en die meervoud van die openbaring plaas. God word in die Nuwe Testament bely as Vader en Seun en Heilige Gees.

Jonker se ander beswaar teen die denke vanuit die Ou Testament oor die Pneumatologie dra nie veel gewig nie. Hy sê: "Word hoofsaaklik vanuit die Ou Testament oor die Gees gedink, dan kan maklik bly steek word in die gedagte dat die Gees skenker is van die lewe van alle dinge (Pannenberg) of dat die Gees die Gees van politieke bevryding is (politieke teologie) of dat die Gees net ' $n$ ander benaming is vir God in sy handelende teenwoordigheid $(B e r k h o f)^{\prime \prime}{ }^{170)}$ Die verkeerde gebruik hef tog nie die regte gebruik op nie!

Wat die rûah be-teken moet immers aan die hand van die Ou Testament beoordeel word. Met die oog hierop is dit sin-vol om uit die stroom van die Ou Testament te drink. Anders gesê: die Ou Testament open helder insigte en uitsigte op die Pneumatologie.

\section{NOTAS}

1. Vir 'n oorsig oor die vulling van die kosmiese werksaamheid van die rûah, vgl: C.J.A. Vos, 
Die Heilige Gees as kosmies-eskatologiese Gawe - 'n eksegeties-dogmatiese studie. Ongepubliseerde proefskrif, Universiteit van Pretoria 1984, 36-38.

Onder die besondere werk van die rûah kan die heilseffektuering ten opsigte van die skepsel verstaan word, terwyl die rûạ̣ se algemene kosmiese werk op die skepping (natuur) gerig is.

2. W.D. Jonker, Die Gees van Christus, Pretoria 1981, 51.

3. W. Dantine, "Die ethische Dimension des pneuma hagion" in Theologie des Geistes (Herausgegeben von Otto A. Dilschneider), Gütersloh 1980, 49.

4. Die skepsel sowel as die skepping se toekoms word Pneumaties in herskeppingskategorieë geteken. Vgl. Vos, a.w., 262-286, 291-293.

5. C. Westermann, "Geist im Alten Testament", Evangelische Theologie 41 (1981), 223.

6. K. Blaser, Vorstoss zur Pneumatologie, Zürich 1977, 9-10.

7. Vir'n voortreflike oorsig oor die gebruik van rûah in die Ou Testament, vgl. R. Albertz en C. Westermann, "ru $\mathrm{a}_{\mathrm{h}}$ Geist" in Theologisches Handwörterbuch zum Alten Testament. Band II. (Herausgegeben von E. Jenni unter Mitarbeit von C. Westermann), München 1971, 726 e.v.; Westermann, "Geist im Alten Testament", Evangelische Theologie 41 (1981), 223 e.v.; R.G. Batcher, "Biblical words describing man: breath, life, spirit", The Bible Translator vol. 34 (2, 1983), $201-205$ en W. Vosloo, "Rûaḥ/gees in die Ou Testament", Skrif en Kerk vol. 2 (1983), 40-63.

8. Albertz en Westermann, a.w., 730.

9. J.A. Heyns, Dogmatiek, Pretoria 1978, 116. My kursivering.

10. A.H. van $\mathrm{Zyl}$, Die Gees van die Here in die lewe van die enkeling volgens die prediking van die Ou Testament, Universiteit van Pretoria, 19 .., 2-3.

11. A. van Selms, Genesis. Deel /, Nijkerk 1967, 24.

12. J.H. Scheepers, Die gees van God en die gees van die mens in die Ou Testament, Kampen 1960, 255.

13. Scheepers, a.w. , 246-263.

14. K. Barth het ook hierop gesinspeel. Kirchliche Dogmatik III/1, Zollikon 1945, 119. Vgl. veral Westermann, Genesis 1-11, Neukirchen-Vluyn 1974, 147.

15. A. König, Hy kan weer en meer, Pretoria 1982, 124.

16. "... een ongewoon hevige wind joeg de wateren op". J. De Fraine, Genesis, Roermond 1963, 31. "De 'wind' is vaak het beeld van het 'niets"' (Jes. 49:21, Job 7:7, Sir. 34:2). Ibid., 34.

17. Westermann, a.w. 1974, 148-149.

18. Ibid., 149.

19. G.J. Hoenderdaal, Geloven in de Heilige Geest, Wageningen 1968, 136.

20. Idem.

21. Idem.

22. Albertz en Westermann, a.w., 730.

23. Vgl. J. Scharbert, Genesis 1-11, Würzburg 1983, 40.

24. Idem.

25. P.F. Theron, Die ekklesia as kosmies-eskatologiese teken, Pretoria 1978, 13.

26. H.-J. Kraus, Psalmen 1-63, Neukirchen-Vluyn 41972, 262.

27. Idem.

28. Albertz en Westermann, a.w., 734.

29. Ibid., 736 .

30. Idem.

31. Ibid., 736-737.

32. Van Selms, a.w., 102.

33. Westermann, a.w. 1974, 282.

34. Albertz en Westermann, a.w., 737; De Fraine, a.w., 115; Westermann, a.w. 1974, 590. Lewensasem dui op die lewe as sodanig. Bratcher, a.w., 202.

35. Bratcher, a.w., 203.

36. Theron, a.w., 13. My kursivering.

37. W. Pannenberg, "Der Geist des Lebens" in Glaube und Wirklichkeit, München 1975, 33. 
38. J. Moltmann, Trinität und Reich Gottes, München 1980, 126. My kursivering. Die mening dat die Gees in die skepping ingegaan het, het 'n panentë̈stiese geur.

39. H. Berkhof, De leer van de Heilige Geest, Nijkerk ${ }^{2} 1965,106$.

40. Kraus, Psa/men 64-150, Neukirchen-Vluyn \$1972, 714.

41. Idem.

42. Albertz en Westermann, a.w., 737.

43. Ibid., 736.

44. Idem.

45. B.J. van der Merwe, Pentateuchtradisies in die Prediking van Deuterojesaja, Groningen $1956,9-10$, werk met dié aanname.

46. W. Van der Meer, "Schepper en schepsel in Jes 42:5" in De Knecht. Studies rondom Deutero-Jesaja. (Aangeboden aan prof. dr. J.L. Koole, De redactie, H.H. Grosheide, C.J. den Heyer et al), Kampen 1978, 124.

47. Ibid., 123.

48. Kraus, Psalmen 64-150, ${ }^{\star 1972,} 916$.

49. Ibid., 918.

50. Vir 'n peiling van die verhouding tussen die Gees en Christus, vgl. Vos, a.w., 150-151, $158-159,162,164$.

51. H. Wildberger, Jesaja 1-12. I. Teilband, Neukirchen-Vluyn 1972, 445.

52. Wildberger, a.w. , 446.

53. Albertz en Westermann, a.w., 750.

54. L.A. Snijders, Jesaja dee/ I, Nijkerk 1969, 145.

55. Idem.; Albertz en Westermann, a.w., 750; Scheepers, a.w., 166; Wildberger, a.w. , 439; J Ridderbos, Jesaja. Eerste deel, Kampen $19 \ldots, 98$.

56. Scheepers, a.w., 166.

57. Ibid., 163. G. Fohrer, Das Buch Jesaja. 1. Band, Zürich ${ }^{2} 1966,167$.

58. Albertz en Westermann, a.W., 743-744; Westermann, "Geist im Alten Testament" Evange/ische Theologie 41 (1981), 225.

59. Wildberger, a.w. 448.

60. W. Zimmerli, Grundriss der alttestamentlichen Theologie, Stuttgart ${ }^{2} 1975,173$.

61. Albertz en Westermann, a.w., 750.

62. Wildberger, a.w., 449; Scheepers, a.w., 164.

63. Idem.

64. Fohrer, a.w., 167; Scheepers, a.w., 164.

65. Scheepers, a.w., 164; Fohrer, a.w., 167; Ridderbos, a.w., 99-100.

66. Fohrer, a.w., 167; Wildberger, a.w., 450

67. Scheepers, a.w., 165; Fohrer, a.w., 167; Snijders, a.w., 145.

68. Wildberger, a.w., 450-455.

69. G.T. Montague, The Holy Spirit: Growth of a Biblical Tradition, New York 1976, 41.

70. Scheepers, a.w., 166; Fohrer, a.w., 168.

71. Scheepers, a.w., 166.

72. Westermann, "Geist im Alten Testament", Evangelische Theologie 41 (1981), 228.

73. R.F. Melugin, The formation of /saiah 50-55, Berlin 1976, veral 82 e.v.; Westermann, Das Buch Jesaja. Kaptel 40-66, Göttingen 41981, 11-28; A. Richter, "Hauptlinien der Deuterojesaja - Forschung von 1964-1979" in Sprache und Struktur der Prophetie Deuterojesajas, Stuttgart 1981, 116-122.

74. Westermann, Theologie des A/ten Testaments, Göttingen 1978, 70. Vir 'n oorsig van die

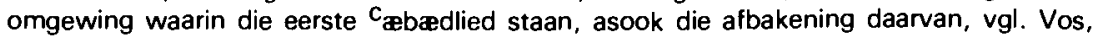
a.w., 86-87.

75. Melugin, a.w. 65-66.

76. Zimmerli, "Pais Theou" in Theologisches Wörterbuch zum Neuen Testament V. (Begründet von G. Kittel. Herausgegeben von G. Friedrich), Stuttgart 1954 [Vorwort], 667; K. Elliger, Deuterojesaja 1. Teilband. Jesaja 40, 1-45, 7, Neukirchen-Vluyn 1978, 199.

77. G. von Rad, Theologie des Alten Testaments. Band I, München 1960, 265, wys op die moontlikheid van hoftaal. 
78. Vgl. Vos, a.w., 88 oor die dienaar se aanstelling en sy uitverkiesing.

79. Westermann, "Geist im Alten Testament", Evangelische Theologie 41 (1981) 225-228; Vosloo, a.w. , 45-57.

80. Westermann, "Geist im Alten Testament", Evangelische Theologie 41 (1981), 227; L. Schmidt, "Kónig und Charisma im AT", Kervgma und Dogma 28 (1982), 85-87.

81. Albertz en Westermann, a.W., 751.

82. Idem.

83. Scheepers, a.w., 175.

84. Von Rad, a.w. 1960, 241.

85. Ibid., 243.

86. Só G. Ch. Aalders, Ezechiël II, Kampen 1957, 190. My kursivering.

87. Zimmerli, Ezechiël, 2 Teilband, Neukirchen-Vluyn 1969, 879; Aalders, a.w., 190.

88. Montague, a.w., 46; Aalders, a.w., 190.

89. Zimmerli, a.w. ${ }^{21975,} 184$

90. Von Rad, a.w. 1960, 250.

91. Zimmerli, a.w. 1969, 878-879.

92. Zimmerli, a.w. 21975, 183; Von Rad, a.w. 1960, 237.

93. Von Rad, Theologie des Alten Testaments. Band I, München ${ }^{5} 1966,167$.

94. Albertz en Westermann, a.w. , 741.

95. Albertz en Westermann, a.w., 751. (Vgl. Ps. 51:12).

96. Aalders, Ezechiël I, Kampen 1955, 200.

97. Zimmerli, a.w. 1969, 879.

98. Al drie frases stamel die totale hooploosheid. Zimmerli, a.w. 1969, 897. Die "bene" is 'n aanduiding van die hele mens (Ps 31:11, Ps 35:10).

99. Albertz en Westermann, a.w., 737.

100. Zimmerli, a.w. 1969, 893.

101. Albertz en Westermann, a.w., 737.

102. Zimmerli, a.w. 1969, 889.

103. Ibid., 897.

104. Idem.

105. Albertz en Westermann, a.w., 751.

106. Zimmerli, a.w. 1969, 898.

107. Elliger, a.w., 390; R.N. Whybray, /saiah 40-66, London 1975, 94.

108. Elliger, a.w., 389-390.

109. Albertz en Westermann, a.w., 752; Elliger, a.w., 390.

110. Elliger, a.w., 391-394.

111. Elliger, a.w., 391; Whybray, a.w., 95.

112. W.S. Prinsloo, The Theology of the Book of Joel, Berlyn 1985 ad loc.; Zimmerli, a.w. 21975, 204.

113. Montague, a.w., 85.

114. Prinsloo, a.w., ad loc.

115. Zimmerli, a.w. ${ }^{2} 1975,204$; Westermann, a.w. 1978, 132-133.

116. Scheepers, a.w., 175.

117. Prinsloo, a.w., ad loc.

118. Prinsloo, a.w., ad loc.

119. Scheepers, a.w., 223 en 292; H.W. Wolff, Dodekapropheten 2. Band XIV/2, NeukirchenVluyn 1969, 78.

120. A. Deissler, Zwölf Propheten Hosea. Joël. Amos, Würtzburg 1981, 81.

121. Scheepers, a.w., 175; Albertz en Westermann, a.w., 751; Wolff, a.w., 80; Deissler, a.w.. 81.

122. Scheepers, a.w., 175.

123. Albertz en Westermann, a.w., 752; Scheepers, a.w., 139; Vosloo, a.w., 61.

124. Wolff, a.w., 79.

125. Scheepers, a.w., 175, 290-292; Deissler, a.w., 81.

126. Prinsloo, a.w., ad loc. 
127. Wolff, a.w., 81; Deissler, a.w., 81-82.

128. Prinsloo, a.w., ad loc.

129. Prinsloo, a.w., ad loc.

130. Westermann, "Geist im Alten Testament", Evangelische Theologie 41 (1981), 225-228.

131. J. Kruis, "Jhwh, Schepper en Formeerder in Deutero-Jesaja" in De Knecht. Studies rondom Deutero-Jesaja, (Aangeboden aan prof. dr. J.L. Koole, De redactie, H.H. Grosheide, C.J. den Heyer et al), Kampen 1978, 84-87.

132. Vgl. Montague, a.w., 51, 64-68, 70; Vosloo, a.w., 61.

133. Scheepers, a.w., 173.

134. Idem.

135. Idem.

136. Idem.

137. Fohrer, Das Buch Jesaja. 2. Band, Zürich ${ }^{2} 1967,132$.

138. Von Rad, a.w. ${ }^{5} 1966,296-297$.

139. Montague, a.w., 40.

140. Fohrer, a.w. ${ }^{2} 1067.132-133$.

141. O. Kaiser, Der Prophet Jesaja. Kapitel 13-39, Göttingen 1973, 265.

142. Fohrer, a.w. ${ }^{2}$ 1967, $132-133$

143. O. Kaiser, Der Prophet Jesaja. Kapitel 13-39, Göttingen 1973, 265.

144. Fohrer, a.w. ${ }^{2}$ 1967, 133.

145. Ibid., 166.

146. Ridderbos, a.w., 103; Wildberger, a.w., 457.

147. Zimmerli, a.w. ${ }^{2} 1975,173$; Fohrer, a.w. ${ }^{2} 1966,169$.

148. Scheepers. a.w. , 216-219; Albertz en Westermann, a.w. , 730-752.

149. Scheepers, a.w., 217.

150. Ibid., 217-218.

151. Westermann, a.w. 1978, 25-27; Zimmerli, Gottes Offenbarung, München 1963, 11-40.

152. Albertz en Westermann, a.w., 742-743.

153. Scheepers, a.w., 207.

154. Ibid., 219; Jonker, a.w., 124; Vosloo, a.w., 63.

155. Westermann, "Geist im Alten Testament", Evangelische Theologie 41 (1981), 228.

156. Idem; Scheepers, a.w., 214.

157. Westermann, "Geist im Alten Testament", Evangelische Theologie 41 (1981), 228; Scheepers, a.w., 208.

158. Albertz en Westermann, a.w. 752. Hieraan kan nog Ps 143:10, Neh 9:20, 30, Mg 3:8 en Sg 7:12, bygevoeg word. Vgl Albertz en Westermann, a.w., 752 en Vosloo, a.w., 62.

159. Scheepers, a.w., 212.

160. Westermann, "Geist im Alten Testament", Evangelische Theologie 41 (1981), 229.

161. Scheepers, a.w., 216, 222.

162. Jonker, a.W., 124. Jonker verklaar op voetspoor van G.A.F. Knight dat "die personifikasie van die Gees en moontlik ook ' $n$ bepaalde vorm van hipostasering van die Gees in die Ou Testament die weg voorberei het vir 'n voller openbaring aangaande die Gees in die Nuwe Testament ..." A.w., 124. My kursivering. Jonker formuleer ook kennelik in die gees van Scheepers: "Deurdat die gees van Jahwe gehipostaseer is, is die weg voorberei vir die voller openbaring van die Gees van God in die Nuwe Testamentiese bedeling". A.w., 222. Dit is egter opmerklik dat Jonker se formulering met betrekking tot die "hipostasering van die Gees in die Ou Testament" versigtig en bók nie so stellig is nie.

163. Vosloo, a.w., 63-64.

164. Aangesien die rûah nie as die derde Persoon in die Goddelike drie-eenheid verstaan kan word nie, het die term hipostase in hierdie samehang nie op die ewige trinitariese belydenis betrekking nie. Dit gaan hier om die noëtiese aspek van God se openbaring in die Ou Testament.

165. Scheepers, a.w., 216; H. Ringgren, "Hypostasen" in Die Religion in Geschichte und Gegenwart. Dritter Band, Tübingen ${ }^{3} 1959,504$.

166. Vosloo, a.w., 62. 
167. Idem

168. W. Eichrodt, Theology of the O/d Testament. Vol 2, London 1967, 60.

169. Jonker, 8.w., 127.

170. Idem. 